\title{
Perancangan Transmitter Gelombang Akustik pada VLF Band untuk Bawah Air
}

\author{
Kania Sawitri ${ }^{1}$, Rustamaji ${ }^{2}$, Rian Mahesa Putra ${ }^{3}$ \\ 1,2,3 Jurusan Teknik Elektro, Institut Teknologi Nasional Bandung \\ Jln. P.K.H. Hasan Mustafa No. 24 Bandung, telp/fax 022-7272215 \\ kania@itenas.ac.id ${ }^{1}$, rustamajisaja@gmail.com²
}

\begin{abstract}
Abstrak - Teknologi akustik saat ini banyak digunakan untuk keperluan sarana navigasi, komunikasi, dan pendeteksian. Sinyal akustik dapat dideteksi dan dihasilkan oleh perangkat transducer electroacoustic. Perangkat untuk mengubah energi akustik menjadi energi listrik disebut hydrophones atau received transducer, dan untuk mengubah energi elektrik menjadi energi akustik disebut proyektor atau transmit transducer. Dalam penelitian ini dilakukan perancangan dan realisasi transmitter (Tx) sinyal akustik pada very low frequency (VLF) band untuk bawah air, terdiri dari pulse signal generator, power amplifier, dan transmit transducer. Berdasarkan hasil pengukuran dan pengujian transmitter (Tx): Tx mampu membangkitkan sinyal suara (gelombang akustik) pada rentang frekuensi 12.67 s.d $33.68 \mathrm{kHz}$; tanpa pelindung anti air mampu memancarkan gelombang akustik (suara) pada rentang frekuensi 13.16 s.d 21.38 $\mathrm{kHz}$, dengan pelindung anti air mampu memancarkan gelombang akustik (suara) pada rentang frekuensi 12.69 s.d $20.75 \mathrm{kHz}$, dan mampu memancarkan gelombang akustik (suara) di dalam air pada rentang frekuensi 13.10 s.d $18.91 \mathrm{kHz}$.
\end{abstract}

Kata Kunci: akustik, pulse signal generator, power amplifier, transmit transducer

\section{Pendahuluan}

Perkembangan teknologi akustik di bidang komunikasi, pencarian obyek-obyek, dan pengukuran bawah air telah ada jauh sebelum Perang Dunia II. Sinyal radio secara alamiah sulit untuk menembus air, sehingga alternatif lain dibutuhkan suatu sensor jarak jauh untuk pencarian dan pengukuran bawah air. Sonar (sound navigation and ranging) sebagai ekivalen dari radar (radio detection and ranging) akustik, untuk pendeteksian bawah air [1].

Pada awalnya, sonar dikenal dengan istilah sonar pasif, dimana hanya dapat menerima sinyal atau gelombang akustik, tanpa bisa mengirim sinyal. Seiring perkembangan teknologi, sonar memiliki kemampuan mengirim dan menerima sinyal akustik, dikenal dengan istilah sonar aktif. Dalam pemanfaatannya pada Perang Dunia I, sonar hanya digunakan untuk keperluan militer. Pada Perang Dunia II, sonar juga digunakan untuk keperluan nonmiliter [2].

Pada mode aktif, sonar membangkitkan pulsa energi suara atau akustik yang kuat. Selanjutnya energi tersebut ditransformasikan menjadi suatu pressure wave (gelombang tekanan) oleh transmit transducer, kemudian dipancarkan ke arah target tertentu. Pulsa tersebut mengenai target dan dipantulkan kembali dalam bentuk echo (gema). Received transducer bertindak untuk menerima (to receive) pantulan gema, dan mengubah kembali tekanan menjadi energi elektrik. Selanjutnya energi elektrik yang sangat lemah diperkuat dan ditampilkan pada layar atau indikator. Jarak ke target ditentukan oleh waktu yang dibutuhkan oleh pulsa untuk memukul target dan kembali lagi, dan besarnya kecepatan suara yang merambat pada air [1].

Pada saat ini, teknologi akustik banyak dimanfaatkan untuk navigasi, komunikasi, pendeteksian, atau pengukuran. Sinyal atau gelombang akustik dapat dibangkitkan dan dideteksi oleh perangkat electroacoustic transducer. Perangkat untuk mengubah energi elektrik menjadi

TELKA, Vol.4, No.1, Mei 2018, pp. 11 23

ISSN (e): 2540-9123

ISSN (p): 2502-1982 
energi akustik disebut projector atau transmit transducer, dan perangkat untuk mengubah energi akustik menjadi energi elektrik disebut hydrophones atau received transducer [3].

Beberapa penelitian tentang transmitter gelombang akustik yang telah dilakukan, diantaranya: penelitian merancang acoustic transmitter menggunakan impact force (semacam electrical hammer) kedalam acoustic resonator untuk membangkitkan suara akustik, tanpa power amplifier [4]. Penelitian merancang high-power mechanical impact transducers untuk aplikasi sonar dan acoustic [5]. Penelitian merancang pembangkit sinyal akustik acak berpulsa untuk menghalau hewan laut [6]. Sedangkan pada penelitian ini merancang transmitter untuk pembangkit sinyal pulsa, dan underwater loudspeaker yang mampu menggetarkan gelombang suara di dalam air dengan menggunakan komponen-komponen elektronik sederhana.

Oleh karena pentingnya fungsi transmitter (Tx) gelombang akustik pada pengukuran bawah air, dan masih terbatasnya penelitian mengenai perangkat transmitter (Tx) bawah air di Indonesia; maka pada penelitian ini dibahas perancangan transmitter (Tx) yang mampu membangkitkan dan memancarkan gelombang akustik (suara) pada very low frequency (VLF) band di bawah air, meliputi: perancangan rangkaian pulse signal generator (pembangkit sinyal pulsa), rangkaian power amplifier (penguat daya), dan transmit transducer (tranduser pancar).

\section{Metodologi}

Pada transmitter (Tx) gelombang akustik, untuk dapat membangkitkan dan memancarkan acoustic wave (gelombang akustik) di dalam air, harus terdapat bagian: pulse signal generator (pembangkit sinyal pulsa) untuk membangkitkan sinyal pulsa pada very low frequency (VLF) band, power amplifier (penguat daya) untuk memperkuat sinyal pulsa, dan transmit transducer (transduser pancar) untuk mengubah sinyal pulsa menjadi gelombang akustik dan memancarkannya di dalam air. Diagram blok transmitter (Tx) gelombang akustik, seperti pada Gambar 1.

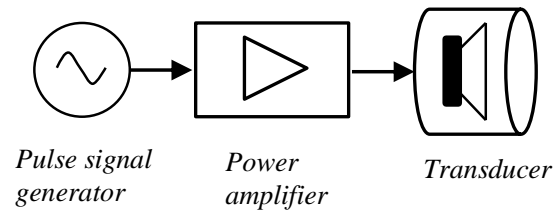

Gambar 1. Diagram blok transmitter $(\mathrm{Tx})$

Metodologi yang digunakan dalam penelitian ini adalah, perancangan dan realisasi "Transmitter (Tx) yang mampu membangkitkan dan memancarkan gelombang akustik pada very low frequency (VLF) band di dalam air" meliputi: perancangan dan realisasi rangkaian pulse signal generator, power amplifier, dan transmit transducer.

Spesifikasi transmitter (Tx) yang direncanakan:

1. Pulse signal generator berupa osilator Hartley yang mampu membangkitkan sinyal pada very low frequency (VLF) band atau frekuensi 3 s.d $30 \mathrm{kHz}$.

2. Power amplifier menggunakan transistor tipe $2 \mathrm{~N} 3055$ dan output transformer (OT).

3. Transmit transducer berupa audio loudspeaker yang dimodifikasi dengan memasang membran tipis dari bahan lateks, sehingga dapat memancarkan gelombang akustik di dalam air.

4. Rangkaian transmitter (Tx) dilindungi dari air menggunakan wadah plastik.

5. Transmitter (Tx) mampu membangkitkan gelombang akustik pada very low frequency (VLF) band.

6. Transmitter (Tx) atau transmit transducer mampu memancarkan gelombang akustik di dalam air. 


\subsection{Perancangan dan Realisasi Pulse Signal Generator}

Rangkaian pulse signal generator yang dirancang berupa osilator Hartley, untuk membangkitkan sinyal pulsa pada very low frequency (VLF) band atau frekuensi 3 s.d $30 \mathrm{kHz}$; direalisasikan menggunakan transistor tipe 2N2222A, seperti pada Gambar 2 [7].

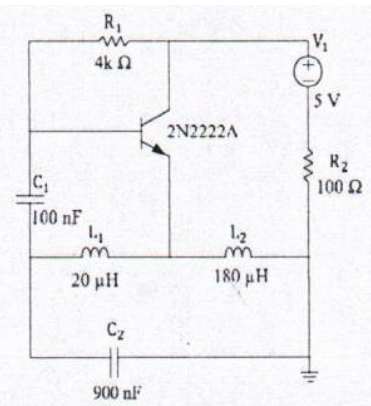

Gambar 2. Realisasi rangkaian pulse signal generator berupa osilator Hartley

Besarnya frekuensi keluaran osilator Hartley dapat dihitung menggunakan persamaan [8]:

$f_{o}=\frac{1}{2 \pi \sqrt{C_{2} \cdot L_{T}}} \mathrm{~Hz}$

dimana:

$L_{T}=L_{1}$ seri $L_{2}=L_{1}+L_{2}=20 \mu \mathrm{H}+180 \mu \mathrm{H}=200 \mu \mathrm{H}$

$C_{2}=900 \mathrm{nF}$

Sehingga:

$f_{o}=\frac{1}{2 \pi \sqrt{\left(900 \times 10^{-9}\right) \cdot\left(200 \times 10^{-6}\right)}}=11.862 \mathrm{kHz}$

Pada realisasinya digunakan nilai $C_{2}$ yang berbeda-beda untuk menghasilkan frekuensi $f_{o}$.

Sedangkan besarnya loop gain:

$A_{V}($ loop $)=g_{m} R_{L}\left(\frac{L_{2}}{L_{1}}\right)$

dengan $g_{m}=0.0015 \mathrm{~A} / \mathrm{V}$, dan $R_{L}=450 \Omega$, diperoleh: $A_{V}($ loop $)=6.075$

Nilai $A_{V}($ loop $)$ sudah memenuhi syarat terjadinya osilasi, yakni: $A_{V}(l o o p)=6.075 \geq 1$.

\subsection{Rangkaian Power Amplifier}

Rangkaian power amplifier yang dirancang untuk memperkuat sinyal keluaran osilator Hartley, berupa OT power amplifier. Direalisasikan menggunakan transistor tipe 2N3055 dan output transformer (OT). Sinyal keluaran power amplifier digunakan untuk menggerakkan transmit transducer berupa audio loudspeaker yang dimodifikasi. Realisasi OT power amplifier seperti pada Gambar 3 [9].

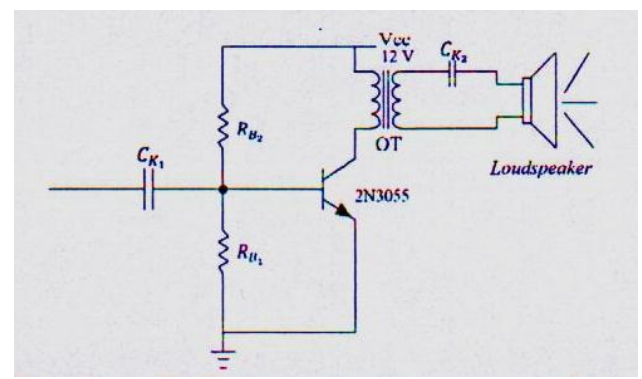

Gambar 3. Realisasi OT power amplifier

Besar penguatan power amplifier ditentukan oleh komponen $R_{B 1}, R_{B 2}$, dan $R_{\mathrm{OT}}=25 \Omega$, seperti pada Gambar 3 [10].

Dari loop output:

$-V_{C C}+V_{R C}+V_{C E Q}=0$ 
untuk transistor $2 \mathrm{~N} 3055$ dengan data: $I_{C_{\max }}=15 \mathrm{~A}, V_{C C}=12 \mathrm{~V}, V_{C E Q}=6 \mathrm{~V}, \beta=70$ diperoleh: $I_{C}=0.24 \mathrm{~A}, \operatorname{dan} I_{B}=0.00343 \mathrm{~A}$.

Dari loop input:

$-V_{T H}+V_{R T H}+V_{B E}=0$

$-\left(\frac{R_{B 1}}{R_{B 1}+R_{B 2}}\right) V_{c C}+\left(\frac{R_{B 1} \cdot R_{B 2}}{R_{B 1}+R_{B 2}}\right) I_{B}+V_{B E}=0$

dengan data $R_{B 1}=244 \Omega, R_{B 2}=20 \mathrm{k} \Omega, I_{B}=0.00343 \mathrm{~A}$

$V_{R T H}=\left(\frac{R_{B 1} \cdot R_{B 2}}{R_{B 1}+R_{B 2}}\right) I_{B}=\left(\frac{244 \cdot 20000}{244+20000}\right) 0.00343=0.83 \mathrm{~V}$

Sehingga diperoleh penguatan tegangan dari power amplifier secara perhitungan:

$A_{V}=\frac{V_{C}}{V_{R T H}}=\frac{6}{0.83}=7.23$

Besarnya kapasitor kopling $C_{k 1}$ untuk frekuensi $f=11.862 \mathrm{kHz}$, dengan $R_{1}=20 \Omega$ adalah:

$C_{k 1}=\frac{1}{2 \pi f\left(R_{1}+\frac{R_{B 1} \cdot R_{B 2}}{R_{B 1}+R_{B 2}}\right)}=\frac{1}{2 \pi\left(11.862 \times 10^{3}\right) \cdot\left(20+\left(\frac{20000 \cdot 244}{20000+244}\right)\right)}=0.0514 \mu \mathrm{F}$

Besarnya kapasitor kopling $C_{k_{2}}$ untuk frekuensi $f=35.588 \mathrm{kHz}$, dengan impedansi output transformer $=23 \Omega$, dan beban berupa loudspeaker dengan impedansi $=4 \Omega$ adalah:

$T=1 / f=R \cdot C_{k 2}$

$C_{k_{2}}=\frac{1}{R \cdot f}=\frac{1}{27 \cdot 35.588 \times 10^{3}}=1.04 \mu \mathrm{F}$

\subsection{Perancangan Transmit transducer}

Transmit transducer yang dirancang untuk mengubah sinyal elektrik keluaran power amplifier menjadi gelombang akustik (suara), sehingga dapat dipancarkan di dalam air. Direalisasikan berupa audio loudspeaker (impedansi $4 \Omega$ ) yang dimodifikasi dengan memasang membran tipis dari bahan lateks pada bagian corong loudspeaker, sehingga dapat memancarkan gelombang akustik dan mampu bekerja di dalam air. Skematik rancangan transmit transducer, seperti pada Gambar 4.

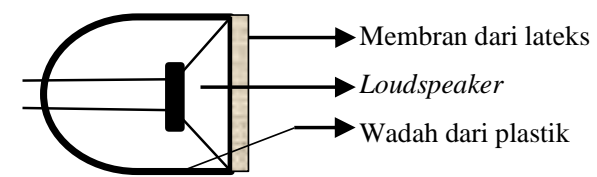

Gambar 4. Skematik rancangan transmit transducer

\subsection{Perancangan Transmitter (Tx) Gelombang Akustik}

Rancangan Tx gelombang akustik, direalisasikan dengan menggabungkan rangkaian osilator Hartley, power amplifier, dan transmit transducer, seperti pada Gambar 5.

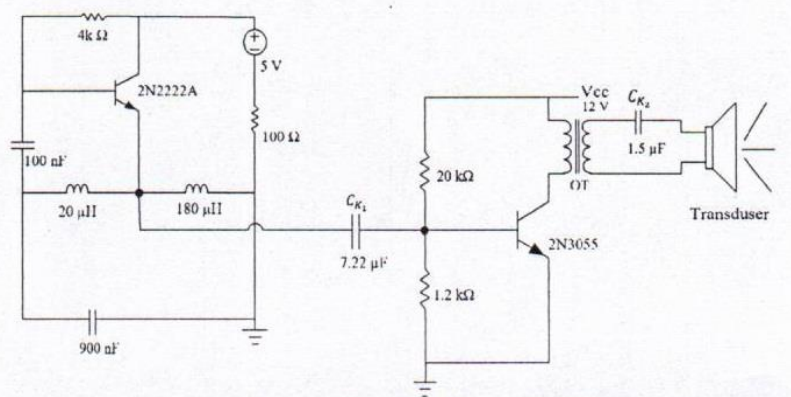

Gambar 5. Realisasi rangkaian transmitter (Tx) gelombang akustik

Pada realisasinya, untuk dapat membangkitkan sinyal pada frekuensi 3 s.d $30 \mathrm{kHz}$, komponen yang digunakan pada Tx adalah: $R_{B 1}=1.2 \mathrm{k} \Omega, R_{B 2}=20 \mathrm{k} \Omega, C_{k 1}=7.22 \mu \mathrm{F}, C_{k 2}=$ $1.5 \mu \mathrm{F}$. Untuk mencegah terjadinya short circuit pada rangkaian saat di dalam air, rangkaian $\mathrm{Tx}$ dibungkus dalam wadah plastik berbentuk bundar dengan tinggi $7.5 \mathrm{~cm}$ dan diameter $10.5 \mathrm{~cm}$. 
Loudspeaker dimodifikasi menjadi transmit transducer, dengan memasang membran tipis dari bahan lateks pada bagian corong loudspeaker, sehingga tahan air dan dapat menghantarkan gelombang akustik di dalam air. Skematik dan realisasi rangkaian Tx dalam wadah plastik, seperti pada Gambar 6(a) dan (b).

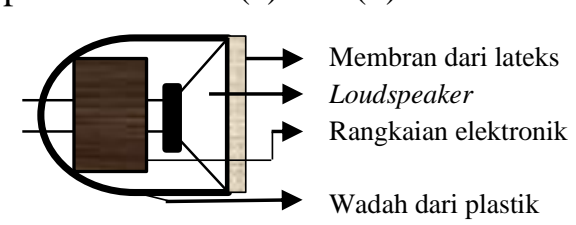

(a)
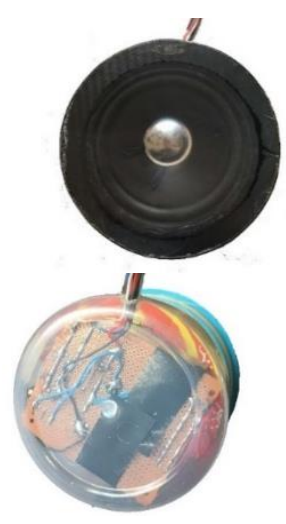

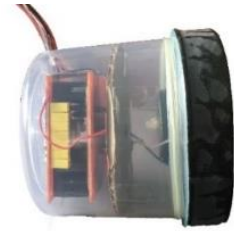

(b)

Gambar 6. (a) Skematik, (b) Realisasi transmitter (Tx) dalam wadah plastik

\section{Pengukuran dan Analisis}

\subsection{Pengukuran Transmitter (Tx) Sinyal Akustik}

Tujuan pengukuran adalah untuk mengetahui karakteristik rangkaian penyusun $\mathrm{Tx}$ dan kemampuannya dalam memancarkan gelombang akustik, pada saat di luar maupun di dalam air. Pengukuran rangkaian Tx yang dilakukan, meliputi:

- Pengukuran tegangan dan frekuensi sinyal keluaran rangkaian pulse signal generator, power amplifier, dan transmit transducer.

- Pengukuran dan pengujian transmitter (Tx) tanpa pelindung anti air.

- Pengukuran dan pengujian transmitter (Tx) dengan pelindung anti air.

- Pengukuran dan pengujian transmitter (Tx) di dalam air.

Pada pengujian di luar dan di dalam air, di sisi kirim adalah transmitter (Tx) gelombang akustik, sedangkan di sisi terima sebagai receiver ( $\mathrm{Rx})$ digunakan hydrophone [11].

\subsubsection{Pengukuran Rangkaian Pulse Signal Generator}

Pengukuran untuk mengetahui amplitudo dan frekuensi sinyal keluaran dari rangkaian pulse signal generator yang realisasinya berupa rangkaian osilator Hartley. Secara teoritis, bentuk sinyal keluaran osilator Hartley berupa sinusoida. Diagram blok pengukuran osilator Hartley, seperti pada Gambar 7.

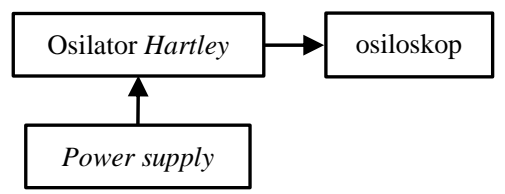

Gambar 7. Diagram blok pengukuran rangkaian osilator Hartley

Dengan nilai kapasitor $C_{2}$ antara 900 s.d $100 \mathrm{nF}$ dari perhitungan hasil perencanaan osilator Hartley, diperoleh rentang frekuensi keluaran antara 11.862 s.d $35.588 \mathrm{kHz}$. Sedangkan dari hasil pengukuran, diperoleh rentang frekuensi keluaran antara 13.23 s.d $33.68 \mathrm{kHz}$. Hasil perhitungan dan pengukuran frekuensi keluaran osilator Hartley seperti pada tabel 1. 
Tabel 1. Hasil perhitungan dan pengukuran sinyal keluaran osilator Hartley untuk nilai kapasitor 900 s.d

\begin{tabular}{|c|c|c|c|}
\hline \multirow{4}{*}{$\begin{array}{c}\text { Kapasitor } \\
(\mathrm{nF})\end{array}$} & Hasil Perhitungan & \multicolumn{2}{c|}{ Hasil Pengukuran } \\
\cline { 2 - 4 } & Frekuensi (kHz) & Frekuensi $(\mathrm{kHz})$ & Tegangan $\left(\mathrm{V}_{\mathrm{p}-\mathrm{p}}\right)$ \\
\hline 900 & 11.862 & 13.23 & 3.03 \\
\hline 800 & 12.582 & 13.62 & 3.75 \\
\hline 700 & 13.451 & 14.37 & 4.63 \\
\hline 600 & 14.528 & 15.06 & 5.36 \\
\hline 500 & 15.915 & 16.18 & 6.15 \\
\hline 400 & 17.794 & 17.61 & 6.63 \\
\hline 300 & 20.546 & 20.08 & 6.96 \\
\hline 200 & 25.164 & 24.33 & 7.36 \\
\hline 100 & 35.588 & 33.68 & 8.00 \\
\hline
\end{tabular}

Terdapat sedikit perbedaan pada besarnya frekuensi yang diperoleh dari hasil perhitungan dan pengukuran, hal ini disebabkan karena nilai toleransi yang dimiliki oleh setiap komponen, menyebabkan frekuensi yang dihasilkan tidak sama. Dari hasil pengukuran untuk kapasitor $C_{2}$ antara $200 \mathrm{s.d} 900 \mathrm{nF}$ diperoleh frekuensi keluaran osilator Hartley sebesar $13.23 \mathrm{s.d} 24.33 \mathrm{kHz}$, dimana nilai ini masih masuk dalam range VLF band. Grafik respons frekuensi keluaran osilator Hartley seperti pada Gambar 8.

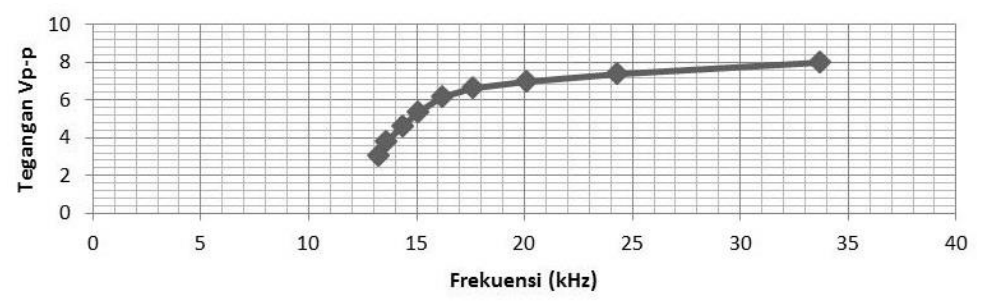

Gambar 8. Grafik respons frekuensi keluaran hasil pengukuran dari osilator Hartley

Sinyal keluaran osilator Hartley mempunyai tegangan tertinggi $=8.00 \mathrm{~V}_{\mathrm{p}-\mathrm{p}}$ pada frekuensi $33.68 \mathrm{kHz}$, dan tegangan terendah sebesar $3.03 \mathrm{~V}_{\mathrm{p} \text {-p }}$ pada frekuensi $13.23 \mathrm{kHz}$. Sinyal keluaran rangkaian osilator Hartley pada tegangan tertinggi dan tegangan terendah berbentuk sinusoida, seperti pada Gambar 9(a) dan (b).
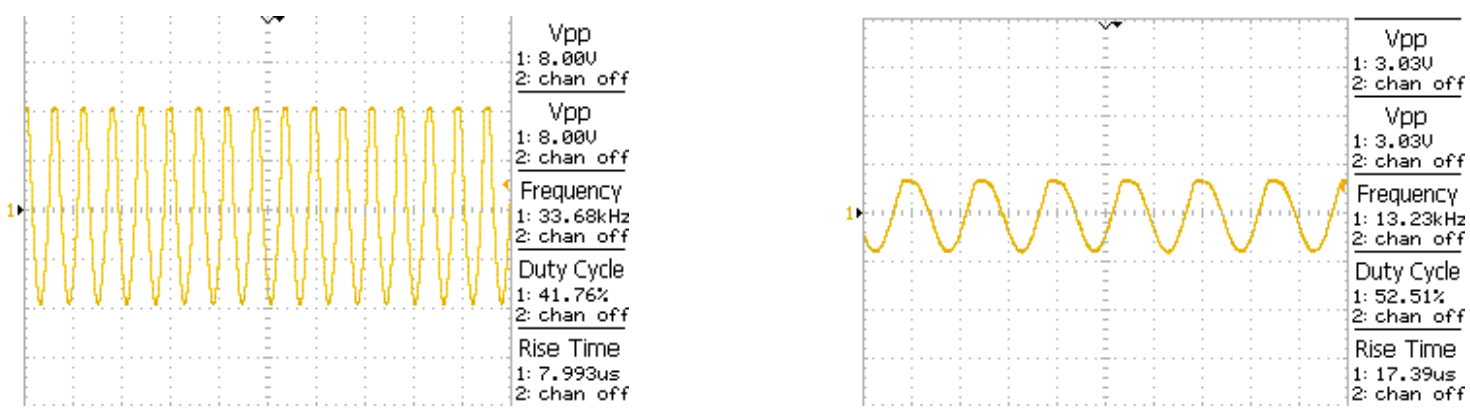

Gambar 9. Sinyal keluaran rangkaian osilator Hartley

(a). Tegangan $8.00 \mathrm{~V}_{\mathrm{p}-\mathrm{p}}$ pada frekuensi $33.68 \mathrm{kHz}$ (b). Tegangan $3.03 \mathrm{~V}_{\mathrm{p}-\mathrm{p}}$ pada frekuensi $13.23 \mathrm{kHz}$

\subsubsection{Pengukuran Rangkaian Power Amplifier}

Pengukuran dilakukan untuk mengetahui besarnya penguatan tegangan pada power amplifier tanpa impedansi beban. Diagram blok pengukuran power amplifier dengan diberi masukan dari rangkaian osilator Hartley, seperti pada Gambar 10. 


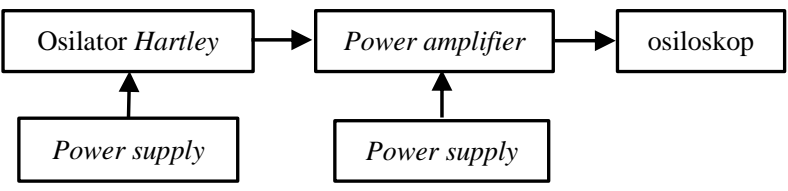

Gambar 10. Diagram blok pengukuran power amplifier

Dari hasil pengukuran dapat diketahui besarnya penguatan tegangan rangkaian power amplifier. Grafik perbandingan respon frekuensi keluaran rangkaian osilator Hartley dan keluaran power amplifier, seperti pada Gambar 11.

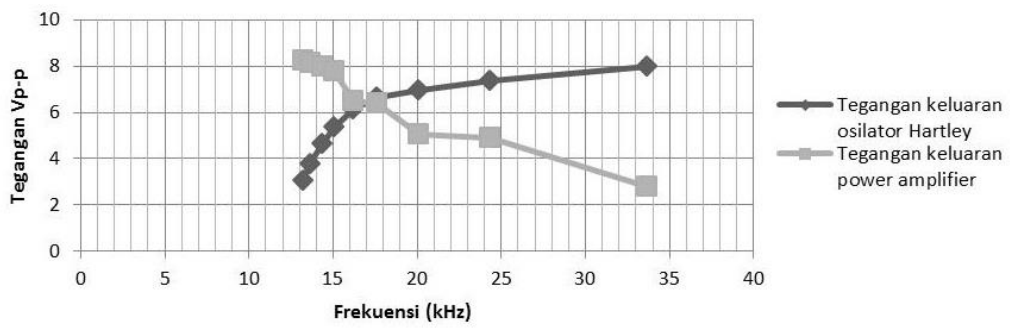

Gambar 11. Grafik perbandingan respons frekuensi keluaran rangkaian osilator Hartley dan power amplifier

Dari Gambar 11, sinyal keluaran power amplifier mempunyai tegangan tertinggi $=8.23 \mathrm{~V}_{\mathrm{p}-\mathrm{p}}$ pada frekuensi $12.97 \mathrm{kHz}$, dan tegangan terendah $=2.79 \mathrm{~V}_{\mathrm{p}-\mathrm{p}}$ pada frekuensi $32.77 \mathrm{kHz}$. Penguatan tegangan tertinggi dari power amplifier $=8.23 / 3.03=2.72$ kali terjadi pada frekuensi $12.97 \mathrm{kHz}$. Mulai terjadi penurunan tegangan pada frekuensi $17 \mathrm{kHz}$, dikarenakan power amplifier hanya mampu menguatkan sinyal pada frekuensi kurang dari $20 \mathrm{kHz}$. Tegangan tertinggi dan tegangan terendah dari sinyal keluaran power amplifier seperti pada Gambar 12(a) dan (b).
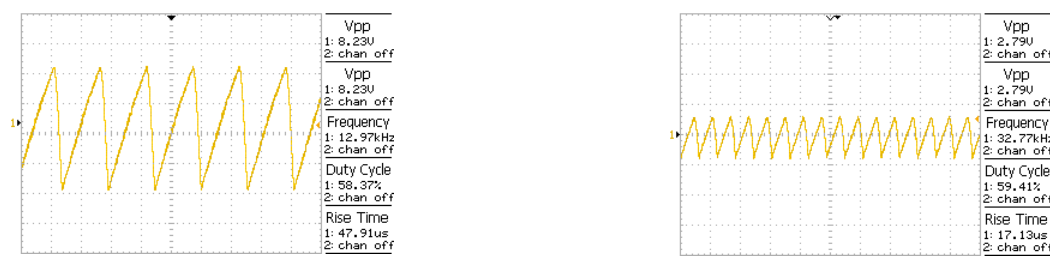

Gambar 12. Sinyal keluaran rangkaian power amplifier

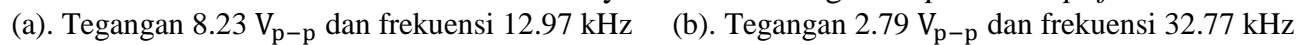

Dari Gambar 12(a) dan (b) terlihat, sinyal keluaran dari rangkaian power amplifier berbentuk bergerigi, tidak sesuai dengan yang diharapkan, berupa sinusoida. Hal ini dikarenakan rangkaian power amplifier belum diberi impedansi beban yang sesuai.

\subsubsection{Pengukuran Rangkaian Transmit transducer}

Pengukuran dilakukan untuk mengetahui sinyal keluaran power amplifier setelah diberi beban berupa transmit transducer (loudspeaker dengan impedansi $=4 \Omega$ ), dan gelombang akustik (suara) yang dihasilkan oleh transmit transducer. Diagram blok pengukuran transmit transducer, seperti pada Gambar 13.

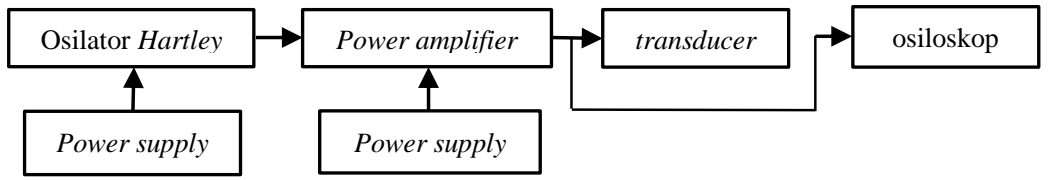

Gambar 13. Diagram blok pengukuran transmit transducer 
Grafik respon frekuensi keluaran power amplifier, antara hasil pengukuran power amplifier tanpa beban dengan power amplifier diberi beban berupa loudspeaker, seperti pada gambar 14 .

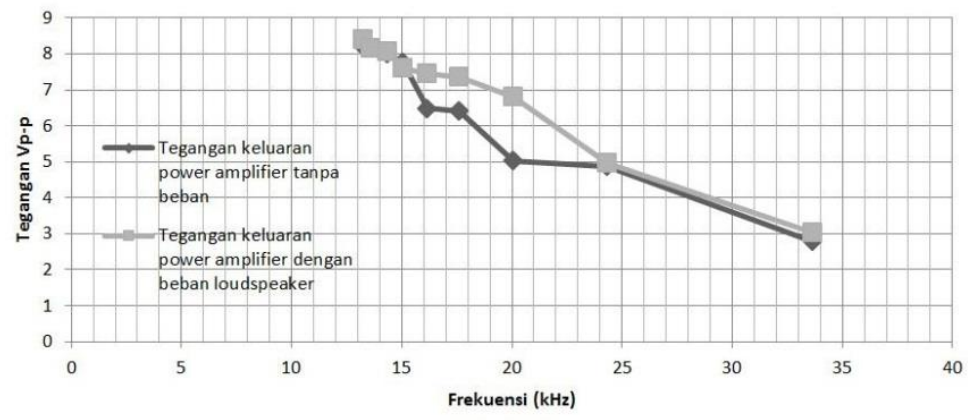

Gambar 14. Perbandingan grafik respon frekuensi keluaran rangkaian power amplifier tanpa beban dan dengan beban loudspeaker

Dari Gambar 14, terlihat terjadi sedikit kenaikan tegangan pada keluaran power amplifier antara 7.44 s.d $6.80 \mathrm{~V}_{\mathrm{p}-\mathrm{p}}$ pada rentang frekuensi 15.98 s.d $20.06 \mathrm{kHz}$, pada saat diberi beban berupa loudspeaker. Sinyal keluaran power amplifier (sebagai masukan transmit transducer) pada tegangan tertinggi dan tegangan terendah seperti pada Gambar 15(a) dan (b).
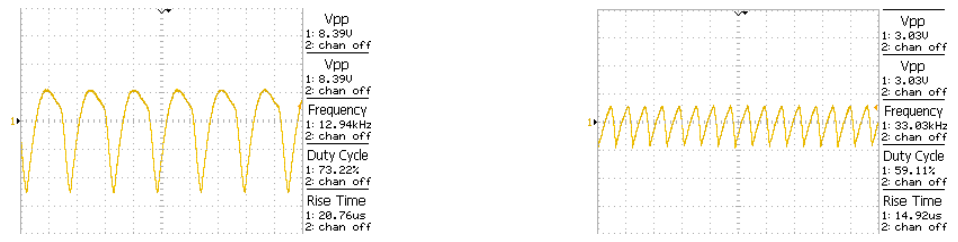

Gambar 15. Sinyal keluaran rangkaian power amplifier

(a). Tegangan $8.39 \mathrm{~V}_{\mathrm{p}-\mathrm{p}}$ dan frekuensi $12.94 \mathrm{kHz}$ (b). Tegangan $3.03 \mathrm{~V}_{\mathrm{p}-\mathrm{p}}$ dan frekuensi $33.03 \mathrm{kHz}$

Dari Gambar 15(a), terlihat bentuk sinyal keluaran power amplifier (sebagai masukan transmit transducer) sudah menyerupai sinusoida. Hal ini dikarenakan antara power amplifier dan loudspeaker dipasang kapasitor kopling sebesar $1.5 \mu \mathrm{F}$, sehingga impedansi power amplifier sesuai (match) dengan impedansi loudspeaker. Dari Gambar 15(b), semakin tinggi frekuensi, semakin kecil amplitudo sinyal keluaran power amplifier. Dengan uji dengar secara langsung, transmit transducer ini sudah dapat bekerja mengeluarkan gelombang akustik (suara) dan terdengar oleh telinga hingga frekuensi $20 \mathrm{kHz}$.

\subsection{Pengukuran dan Pengujian Transmitter (Tx) Tanpa Pelindung Anti Air}

Pengukuran dan pengujian ini dilakukan untuk mengetahui kemampuan kerja transmitter (Tx) memancarkan gelombang akustik (suara), dan dapat diterima oleh receiver ( $\mathrm{Rx}$ ) pada jarak tertentu. Pada pengukuran ini dipasang beban berupa transmit transducer (loudspeaker dengan impedansi $=4 \Omega$ ) tanpa menggunakan pelindung anti air. Diagram blok pengukuran dan pengujian rangkaian Tx tanpa pelindung anti air, seperti pada Gambar 16.

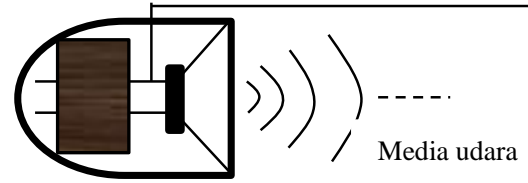

Transmitter (Tx)

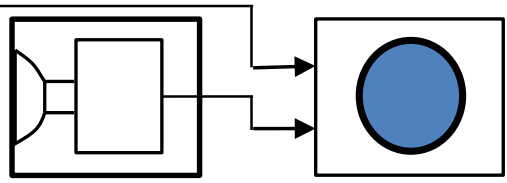

Receiver (Rx)
Osiloskop

Gambar 16. Diagram blok pengukuran dan pengujian transmitter (Tx) tanpa pelindung anti air 
Pengukuran dan pengujian Tx dilakukan di dalam bak dengan panjang $55 \mathrm{~cm}$ dan tinggi 35 cm tanpa berisi air, sebagai receiver $(\mathrm{Rx})$ di sisi terima digunakan hydrophone. Tata letak pengukuran dan pengujian rangkaian Tx tanpa pelindung anti air, seperti pada Gambar 17.

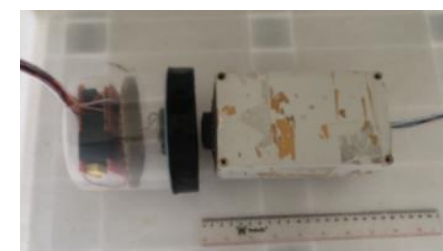

Gambar 17. Tata letak pengukuran dan pengujian transmitter (Tx) tanpa pelindung anti air

Sinyal hasil pengukuran dan pengujian Tx pada frekuensi $13.19 \mathrm{kHz}$, dilakukan untuk setiap jarak antara Tx dan Rx sejauh $5 \mathrm{~cm}$, seperti pada Gambar 18.

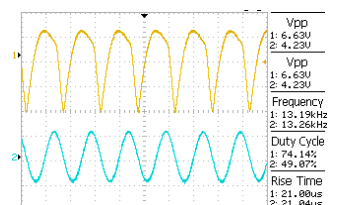

a. Jarak $5 \mathrm{~cm}$

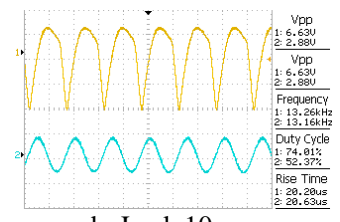

b. Jarak $10 \mathrm{~cm}$

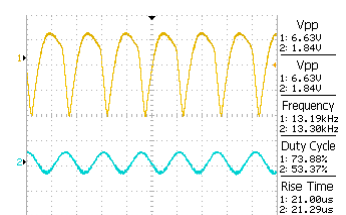

c. Jarak $15 \mathrm{~cm}$

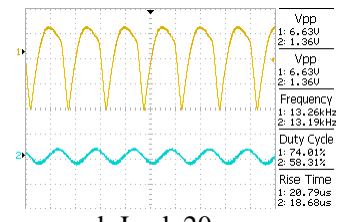

d. Jarak $20 \mathrm{~cm}$

Gambar 18. Sinyal hasil pengukuran dan pengujian transmitter (Tx) pada frekuensi $13.19 \mathrm{kHz}$, untuk setiap jarak antara Tx dan Rx sejauh $5 \mathrm{~cm}$

Dari Gambar 18, Rx mampu menerima sinyal dari Tx dengan baik pada tegangan= $6.63 \mathrm{~V}_{\mathrm{p}-\mathrm{p}}$, dan tegangan sinyal keluaran $\mathrm{Rx}=4.23 \mathrm{~s} . \mathrm{d} 1.36 \mathrm{~V}_{\mathrm{p}-\mathrm{p}}$ untuk jarak $5 \mathrm{~s} . \mathrm{d} 20 \mathrm{~cm}$. Hal ini dikarenakan transmit transducer (loudspeaker) di Tx dapat menghasilkan suara dengan jelas, sehingga sinyal dapat diterima oleh Rx dengan baik.

Selanjutnya pengukuran dan pengujian Tx pada frekuensi $20.83 \mathrm{kHz}$. Sinyal hasil pengukuran dan pengujian untuk setiap jarak antara Tx dan Rx sejauh $5 \mathrm{~cm}$, seperti pada Gambar 19.
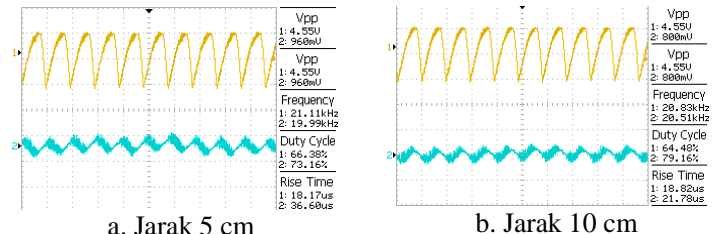

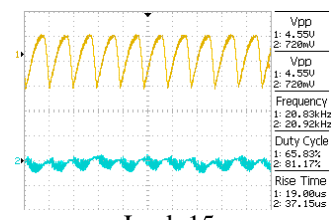

c. Jarak $15 \mathrm{~cm}$

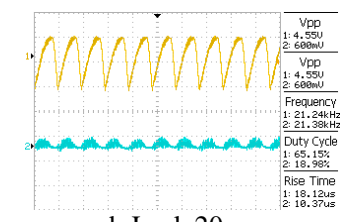

d. Jarak $20 \mathrm{~cm}$

Gambar 19. Sinyal hasil pengukuran dan pengujian transmitter (Tx) dan receiver $(\mathrm{Rx})$ pada frekuensi $20.83 \mathrm{kHz}$ untuk setiap jarak antara Tx dan Rx sejauh $5 \mathrm{~cm}$

Dari Gambar 19, Rx tidak mampu menerima sinyal yang dikirimkan Tx, pada tegangan sebesar $4.55 \mathrm{~V}_{\mathrm{p}-\mathrm{p}}$. Hal ini dikarenakan transmit transducer (loudspeaker) di Tx tidak mampu menghasilkan suara dengan jelas pada frekuensi lebih dari $20 \mathrm{kHz}$. Tegangan keluaran pada $\mathrm{Rx}=$ 960 s.d $600 \mathrm{mV}_{\mathrm{p}-\mathrm{p}}$.

Pengukuran dan pengujian pada frekuensi $32.26 \mathrm{kHz}, \mathrm{Rx}$ sama sekali tidak mampu menerima sinyal, karena transmit transducer (loudspeaker) di Tx tidak mampu menghasilkan suara pada frekuensi tersebut, sehingga tidak dapat memancarkan gelombang akustik (suara).

\subsection{Pengukuran dan Pengujian Transmitter (Tx) dengan Pelindung Anti Air.}

Untuk mengetahui kemampuan kerja Tx dengan pelindung anti air di luar air, dilakukan pengukuran dan pengujian Tx dengan pelindung anti air, seperti pada Gambar 20. 


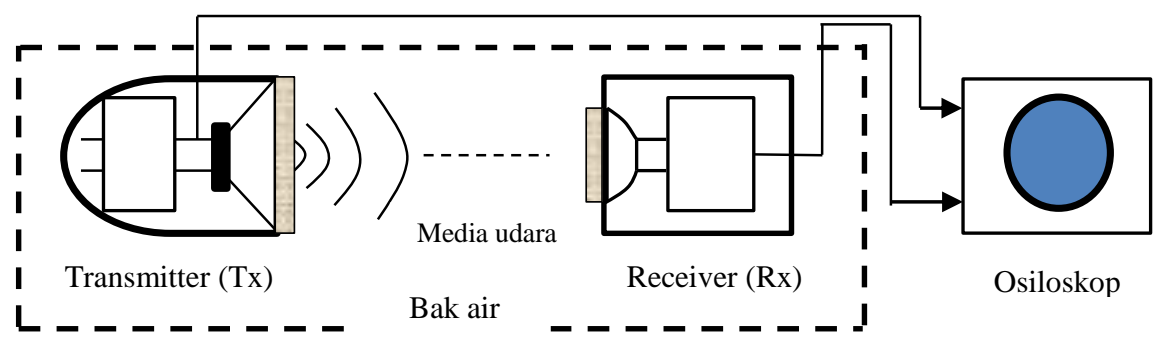

Gambar 20. Diagram blok pengukuran dan pengujian transmitter (Tx) dengan pelindung anti air

Pada pengukuran dan pengujian Tx ini, transmit transducer berupa audio loudspeaker sudah dimodifikasi dengan memasang membran tipis dari bahan lateks pada corong loundspeaker, sehingga dapat memancarkan gelombang akustik di dalam air. Hal ini dilakukan untuk melihat kemampuan kerja Tx di luar air, sebelum dilakukan pengujian di dalam air. Pengukuran dan pengujian dilakukan di dalam bak dengan panjang $55 \mathrm{~cm}$ dan tinggi $35 \mathrm{~cm}$ tanpa berisi air, seperti pada Gambar 21.

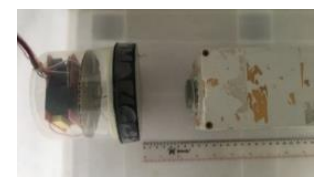

Gambar 21. Tata letak pengukuran dan pengujian rangkaian transmitter (Tx) dengan pelindung anti air

Sinyal hasil pengukuran dan pengujian Tx dan receiver $(\mathrm{Rx})$ pada frekuensi $12.67 \mathrm{kHz}$ dilakukan untuk setiap jarak antara Tx dan Rx sejauh $5 \mathrm{~cm}$, seperti pada Gambar 22.

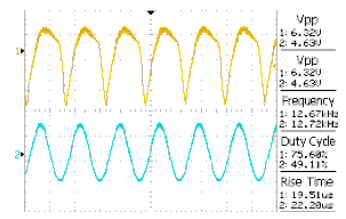

a. Jarak $5 \mathrm{~cm}$

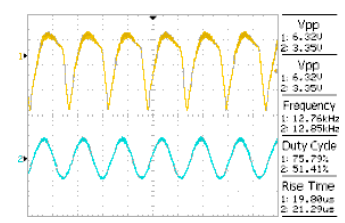

b. Jarak $10 \mathrm{~cm}$

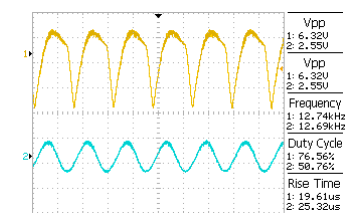

c. Jarak $15 \mathrm{~cm}$

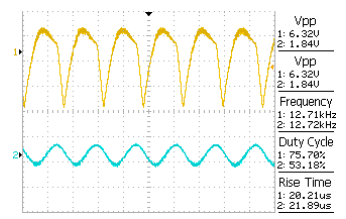

d. Jarak $20 \mathrm{~cm}$

Gambar 22. Sinyal hasil pengukuran dan pengujian transmitter (Tx) pada frekuensi $12.67 \mathrm{kHz}$ untuk setiap jarak antara Tx dan Rx sejauh $5 \mathrm{~cm}$

Dari Gambar 22, Rx mampu menerima sinyal dari Tx dengan baik pada tegangan sebesar $6.32 \mathrm{~V}_{\mathrm{p}-\mathrm{p}}$. Hal ini dikarenakan transmit transducer pada Tx dapat menghasilkan suara dengan jelas, sehingga sinyal dapat diterima oleh Rx dengan baik. Tegangan keluaran Rx $=4.63$ s.d 1.84 $\mathrm{V}_{\mathrm{p}-\mathrm{p}}$.

Selanjutnya pengukuran dan pengujian Tx pada frekuensi $20.79 \mathrm{kHz}$. Sinyal hasil pengukuran dan pengujian Tx untuk setiap jarak antara Tx dan Rx sejauh $5 \mathrm{~cm}$, seperti pada Gambar 23.

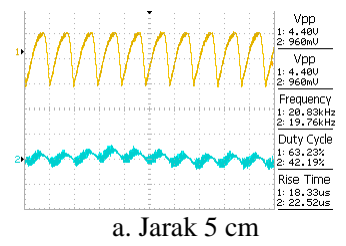

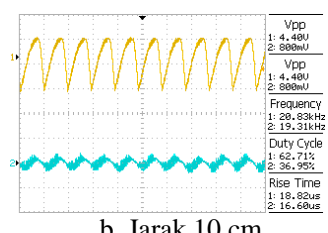

b. Jarak $10 \mathrm{~cm}$

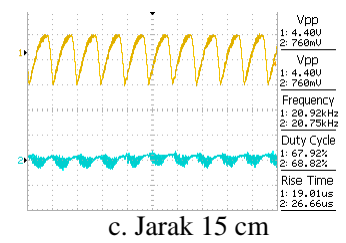

c. Jarak $15 \mathrm{~cm}$

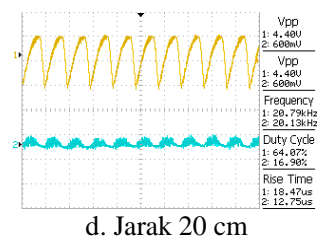

d. Jarak $20 \mathrm{~cm}$

Gambar 23. Sinyal hasil pengukuran dan pengujian transmitter (Tx) pada frekuensi $20.79 \mathrm{kHz}$ untuk setiap jarak antara Tx dan Rx sejauh $5 \mathrm{~cm}$

Dari Gambar 23, Rx tidak mampu menerima sinyal yang dikirimkan Tx pada tegangan sebesar $4.40 \mathrm{~V}_{\mathrm{p}-\mathrm{p}}$. Hal ini dikarenakan transmit transducer di Tx tidak mampu menghasilkan 
suara dengan jelas pada frekuensi lebih dari $20 \mathrm{kHz}$. Tegangan keluaran pada Rx $=960$ s.d 600 $\mathrm{mV}_{\mathrm{p}-\mathrm{p} \text {. }}$

Pada frekuensi $32.79 \mathrm{kHz}$, Rx sama sekali tidak mampu menerima sinyal karena transmit transducer di Tx tidak mampu menghasilkan suara pada frekuensi lebih dari $20 \mathrm{kHz}$, sehingga tidak dapat memancarkan gelombang akustik (suara). Dari pengukuran dan pengujian dapat dikatakan, penggunaan membran tipis dari bahan lateks pada transmit transducer (loudspeaker) berfungsi dengan benar untuk meneruskan getaran akustik melalui udara sampai ke Rx.

\subsection{Pengukuran dan Pengujian Transmitter (Tx) di dalam Air}

Pengukuran dan pengujian ini bertujuan untuk mengetahui kemampuan kerja $\mathrm{Tx}$ sebagaimana alat aslinya untuk menghasilkan gelombang akustik (suara) pada saat di dalam air. Diagram blok pengukuran dan pengujian Tx di dalam air seperti pada Gambar 24.

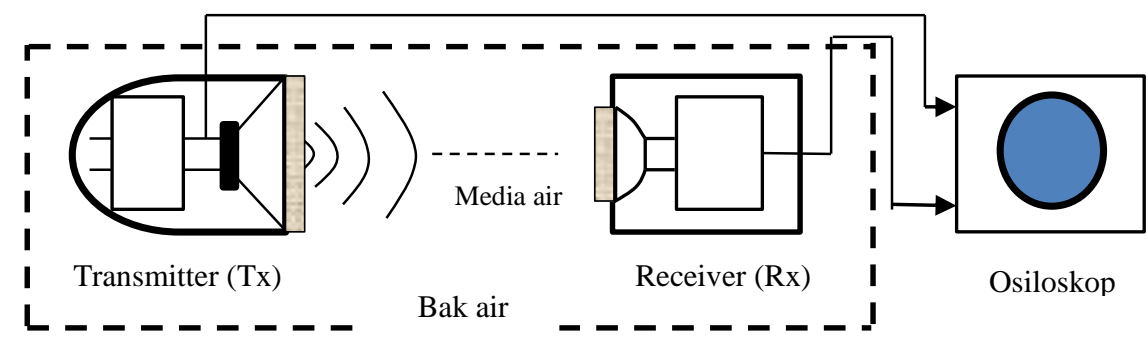

Gambar 24. Diagram blok pengukuran dan pengujian transmitter (Tx) di dalam air

Pada pengukuran ini, transmit transducer berupa audio loudspeaker sudah dimodifikasi dengan memasang membran tipis dari bahan lateks pada corong loudspeaker, sehingga dapat memancarkan gelombang akustik di dalam air. Pengukuran dan pengujian dilakukan di dalam air pada sebuah bak dengan panjang $55 \mathrm{~cm}$ dan tinggi $35 \mathrm{~cm}$. Pengukuran dan pengujian Tx di dalam air, seperti pada Gambar 25.

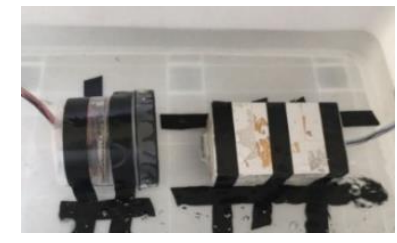

Gambar 25. Pengukuran dan pengujian transmitter (Tx) di dalam air

Tabel 2. Hasil pengukuran sinyal keluaran transmitter (Tx) dan receiver ( $\mathrm{Rx}$ ) di dalam air

\begin{tabular}{|c|c|c|c|c|c|c|c|c|c|c|c|c|c|c|c|c|}
\hline \multirow{3}{*}{$\begin{array}{c}\text { Kapasitor } \\
\text { (nF) }\end{array}$} & \multicolumn{4}{|c|}{ Jarak $5 \mathrm{~cm}$} & \multicolumn{4}{|c|}{ Jarak $10 \mathrm{~cm}$} & \multicolumn{4}{|c|}{ Jarak $15 \mathrm{~cm}$} & \multicolumn{4}{|c|}{ Jarak $20 \mathrm{~cm}$} \\
\hline & \multicolumn{2}{|c|}{$T x$} & \multicolumn{2}{|c|}{$\mathrm{Rx}$} & \multicolumn{2}{|c|}{$\mathrm{Tx}$} & \multicolumn{2}{|c|}{$R x$} & \multicolumn{2}{|c|}{ Tx } & \multicolumn{2}{|c|}{$\mathrm{Rx}$} & \multicolumn{2}{|c|}{ Tx } & \multicolumn{2}{|c|}{$R x$} \\
\hline & $\begin{array}{c}\text { Teg } \\
\left(V_{D-p}\right)\end{array}$ & $\begin{array}{l}\text { Frek } \\
(\mathrm{Hz})\end{array}$ & $\begin{array}{l}\text { Teg } \\
\left(V_{p-p}\right)\end{array}$ & $\begin{array}{l}\text { Frek } \\
(\mathrm{Hz})\end{array}$ & $\begin{array}{c}\text { Teg } \\
\left(V_{D-p}\right)\end{array}$ & $\begin{array}{l}\text { Frek } \\
(\mathrm{Hz})\end{array}$ & $\begin{array}{c}\text { Teg } \\
\left(\mathrm{V}_{\mathrm{p}-\mathrm{p}}\right)\end{array}$ & $\begin{array}{l}\text { Frek } \\
(\mathrm{Hz})\end{array}$ & $\begin{array}{c}\text { Teg } \\
\left(V_{p-p}\right)\end{array}$ & $\begin{array}{l}\text { Frek } \\
(\mathrm{Hz})\end{array}$ & $\begin{array}{c}\text { Teg } \\
\left(V_{p-p}\right)\end{array}$ & $\begin{array}{l}\text { Frek } \\
(\mathrm{Hz})\end{array}$ & $\begin{array}{c}\text { Teg } \\
\left(V_{D-p}\right)\end{array}$ & $\begin{array}{l}\text { Frek } \\
(\mathrm{Hz})\end{array}$ & $\begin{array}{l}\text { Teg } \\
\left(V_{\text {D-p }}\right)\end{array}$ & $\begin{array}{l}\text { Frek } \\
(\mathrm{Hz})\end{array}$ \\
\hline 900 & 6.4 & 13.26 & 1.24 & 13.16 & 6.4 & 13.19 & 0.84 & 13.19 & 6.4 & 13.23 & 0.8 & 13.23 & 6.4 & 13.25 & 0.76 & 13.25 \\
\hline 800 & 6.32 & 13.58 & 1.12 & 13.85 & 6.32 & 13.79 & 1.0 & 13.74 & 6.32 & 13.76 & 0.8 & 13.51 & 6.32 & 13.76 & 0.72 & 13.85 \\
\hline 700 & 6.15 & 14.53 & 0.92 & 14.75 & 6.15 & 14.49 & 0.84 & 14.4 & 6.15 & 14.49 & 0.72 & 14.4 & 6.15 & 14.54 & 0.6 & 14.77 \\
\hline 600 & 5.92 & 15.66 & 0.88 & 15.96 & 5.92 & 15.34 & 0.76 & 15.34 & 5.92 & 15.51 & 0.52 & 15.31 & 5.92 & 15.75 & 0.44 & 15.48 \\
\hline 500 & 5.67 & 16.56 & 0.88 & 16.75 & 5.67 & 16.56 & 0.72 & 16.12 & 5.67 & 16.61 & 0.68 & 16.49 & 5.67 & 16.62 & 0.64 & 16.34 \\
\hline 400 & 5.59 & 18.18 & 0.8 & 18.91 & 5.59 & 18.32 & 0.76 & 18.59 & 5.59 & 18.25 & 0.72 & 18.91 & 5.59 & 18.18 & 0.6 & 18.15 \\
\hline 300 & 4.23 & 21.01 & 0.72 & - & 4.23 & 20.95 & 0.64 & - & 4.23 & 21.1 & 0.56 & - & 4.23 & 20.95 & 0.48 & - \\
\hline 200 & 3.2 & 25.52 & 0.64 & - & 3.2 & 25.38 & 0.56 & - & 3.2 & 25.67 & 0.48 & - & 3.2 & 25.38 & 0.4 & - \\
\hline 100 & 3.11 & 32.88 & 0.64 & - & 3.11 & 32.4 & 0.56 & - & 3.11 & 32.56 & 0.48 & - & 3.11 & 32.33 & 0.4 & - \\
\hline
\end{tabular}

Sinyal hasil pengukuran dan pengujian Tx pada frekuensi $13.19 \mathrm{kHz}$ dilakukan untuk setiap jarak antara Tx dan Rx sejauh $5 \mathrm{~cm}$, seperti pada Gambar 26. 


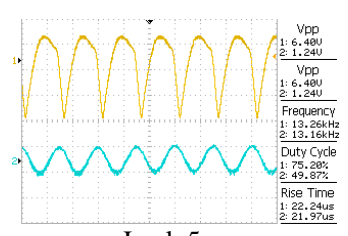

a. Jarak $5 \mathrm{~cm}$

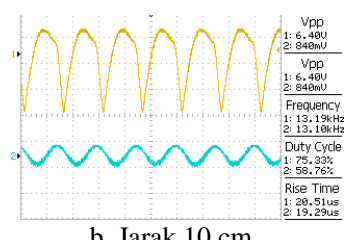

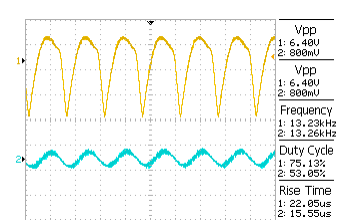

c. Jarak $15 \mathrm{~cm}$

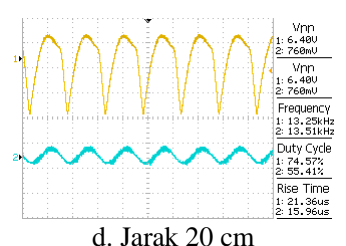

d. Jarak $20 \mathrm{~cm}$ setiap jarak antara Tx dan Rx sejauh $5 \mathrm{~cm}$

Dari Gambar 26, Rx mampu menerima sinyal dari Tx dengan baik pada tegangan sebesar $6.40 \mathrm{~V}_{\mathrm{p}-\mathrm{p}}$. Tegangan keluaran pada Rx mengalami penurunan setiap jarak meningkat, dari 1.24 s.d $7.60 \mathrm{mV}_{\mathrm{p}-\mathrm{p}}$. Hal ini terjadi karena adanya redaman propagasi di dalam air.

Selanjutnya dilakukan pengukuran dan pengujian Tx pada frekuensi $20.95 \mathrm{kHz}$. Sinyal hasil pengukuran dan pengujian Tx untuk setiap jarak antara Tx dan Rx sejauh $5 \mathrm{~cm}$, seperti pada Gambar 27.

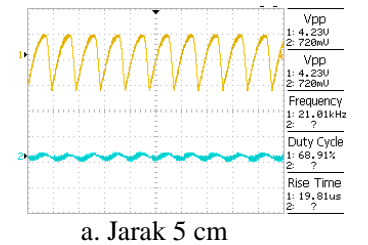

a. Jarak $5 \mathrm{~cm}$

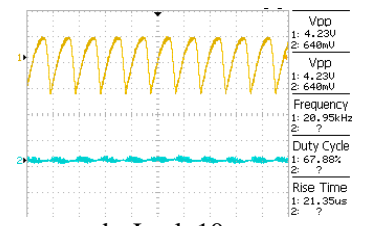

b. Jarak $10 \mathrm{~cm}$

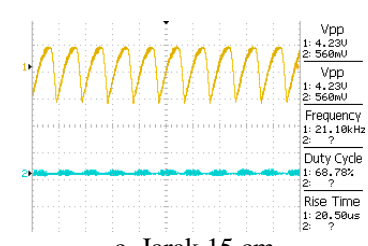

c. Jarak $15 \mathrm{~cm}$

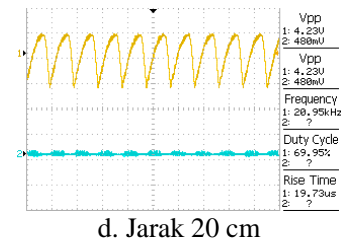

Gambar 27. Sinyal hasil pengukuran dan pengujian transmitter (Tx) pada frekuensi $20.95 \mathrm{kHz}$ untuk setiap jarak antara Tx dan Rx sejauh $5 \mathrm{~cm}$

Dari Gambar 27, Rx sama sekali tidak mampu menerima sinyal yang dikirimkan dari Tx pada tegangan sebesar $4.23 \mathrm{~V}_{\mathrm{p}-\mathrm{p}}$. Hal ini dikarenakan transmit transducer di Tx tidak mampu menghasilkan gelombang akustik (suara) pada frekuensi diatas $20 \mathrm{kHz}$. Tegangan keluaran pada $\mathrm{Rx}=720$ s.d $480 \mathrm{~m} \mathrm{~V} \mathrm{p}$. .

Dari pengukuran dan pengujian dapat dikatakan, penggunaan membran tipis dari bahan lateks pada transmit transducer (loudspeaker) berfungsi dengan benar untuk meneruskan getaran akustik (suara) melalui air sampai ke Rx. Dari hasil pengukuran dan pengujian ini, dikatakan Tx dapat memancarkan gelombang akustik (suara) di dalam air pada range frekuensi 13.10 s.d 18.91 $\mathrm{kHz}$.

\section{Kesimpulan}

Setelah melakukan perancangan, pengukuran, pengujian, dan menganalisis rangkaian transmitter (Tx), pada jarak transmitter (Tx) dan receiver $(\mathrm{Rx})$ antara $5 \mathrm{s.d} 20 \mathrm{~cm}$, maka dapat diambil beberapa kesimpulan sebagai berikut:

1. Transmitter $(\mathrm{Tx})$ yang dirancang mampu menghasilkan gelombang akustik dalam rentang frekuensi 12.67 s.d $33.68 \mathrm{kHz}$.

2. Transmitter (Tx) pada kondisi di luar air dan tanpa pelindung anti air, mampu mengirimkan sinyal ke receiver $(\mathrm{Rx})$. Receiver $(\mathrm{Rx})$ dapat menerima gelombang akustik pada rentang frekuensi 13.16 s.d $21.38 \mathrm{kHz}$.

3. Transmitter (Tx) pada kondisi di luar air dan menggunakan pelindung anti air, mampu mengirimkan sinyal ke receiver $(\mathrm{Rx})$. Receiver $(\mathrm{Rx})$ dapat menerima gelombang akustik pada rentang frekuensi 12.69 s.d $20.75 \mathrm{kHz}$.

4. Penggunaan membran tipis dari bahan lateks pada transmit transducer (loudspeaker) berfungsi dengan benar untuk meneruskan getaran akustik melalui air sampai receiver ( $\mathrm{Rx})$.

5. Transmitter (Tx) mampu bekerja di dalam air dan mampu mengirimkan sinyal ke receiver (Rx). Receiver $(\mathrm{Rx})$ dapat menerima gelombang akustik pada rentang frekuensi 13.10 s.d $18.91 \mathrm{kHz}$ pada saat di dalam air. 


\section{Daftar Pustaka}

[1] Sam Kelly. Experimental Oceanography. Howard W. Sams \& Co., Inc. The Bobbs-Merrilll Co., Inc, (1975).

[2] Randal, R.E. Elements of Ocean Engineering, http://traktoria.org/ files/sonar/Underwater_Acoustics_short_summary.pdf , (1997).

[3] Au, W.W.L., \& Hastrings, M.C. Measurement and Generation of Underwater Sounds. http://www.springer.com/cda/content/document/cda_Downloaddocument/978038778342c2.pdf?SGWID=0-0-45-721433p173807664. (2008).

[4] Chung Chang and Richard Coates, A novel underwater acoustic transmitter. The Journal of the Acoustical Society of America 117, 2447; https://doi.org/10.1121/1.1919908, (2005).

[5] Franklin Felber. Low-cost, high-power mechanical impact transducers for sonar and acoustic through-wall surveillance applications. Physics Division, Starmark, Inc., P. O. Box 270710, San Diego, CA 92198

[6] Yusmar Palapa W, Pembangkit Sinyal Akustik Acak Berpulsa Menggunakan EFM32. Politeknik Caltex Riau (2003).

[7] Stan Zurek, Magnetica http://www.encyclopedia-magnetica.com/doku.php/squegging, (2014).

[8] Rustamaji, Elektronika Komunikasi. Penerbit Itenas. Bandung. ISBN: 978-602-74127-2-9, (2017).

[9] Transistor Circuits, Handbook of the American, European and Japanese Transistors (1985).

[10] Rustamaji, Rahmiati, P., \& Nofiardiman, S,. Perancangan Prototipe Penguat dan Transduser untuk Komunikasi Bawah Air. Jurnal Reka Elkomika. 5(2), (2017).

[11] Hidayat, N.W.,Perancangan Prototipe Hydrophone untuk Komunikasi Bawah Air. Program Sarjana. Institut Teknologi Nasional Bandung, (2016). 